Мирјана М. Бечејски ${ }^{1}$

Институт за српску културу

Приштина - Аепосавић

\title{
ПРОМЕТЕЈСКЕ ИДЕЈЕ У ДЕЛУ ДАНИЛА КИША²
}

Апстракт: Циьрадаједапрати итумачи појаву, развој, вариратье ипромишььате прометејских идеја у ктижевном делу и животној филозофији Аанила Киша. Полазећи од типологије савременог побуненика/ изгнаника коју је понудио Морис Фридман у къизи Проблематични побуњеник („модерни Прометеј” и „модерни Јов"), аутор скреће пажку на разлику између изворног прометејства које подразумева побуну у оквиру друштвеног и космичког поретка, имодерног прометејства - чија је побуна усмерена против тог поретка. Ово друго схватате допринело је томе да прометејство постане универзални кьижевни појам за одређени тип (побуюеничког) односа према стварности, који инсистира на питану смисла самог постојата. У раду се најпре анализирају фигуре песникапобуненика и промишьағе прометејства у Кишовојраној есејистищи и роману Мансарда, потом фигуре проблематичног побуњеника између „Прометеја и Јова" у породичној трилогији и Прометеја-Натчовека у „Гробнищи за Бориса Аавидовича" и, на крају, гностички побуњеници у причи „Симон Чудотворач” и у последюим есејима и интервјуима, у којима се писач опсесивно враћа прометејству и самм се експлицитно представља као модерни побуненик.

Къучне речи: Аанило Кии, модерни Прометеј, модерни Јов, гностички побуненик, Симон Маг, хришћанство, прометејскимит, сумға, догма, уметност.

\section{Појам прометејства}

Премда термин прометејство на први поглеА Аелује саморазумьиво, потреба за његовим одређењем намеће се сваки пут кад се конкретније говори

\footnotetext{
${ }^{1}$ Истраживач-сарадник Института за српску културу Приштина- Аепосавић. ИмејА-aApeca: becejskim@gmail.com.

${ }^{2} \mathrm{PaA} \mathrm{је} \mathrm{настао} \mathrm{у} \mathrm{оквиру} \mathrm{пројекта} \mathrm{Материјална} \mathrm{и} \mathrm{духовна} \mathrm{култура} \mathrm{Косова} \mathrm{и} \mathrm{Метохије} \mathrm{(ев.} \mathrm{бр.}$ $178028)$, који у целини финансира Министарство просвете, науке и технолошког развоја Републике Србије.
} 
о прометејским идејама у савременој књижевности. Будући да ту више није реч о књижевној обради првобитне митске приче о Прометеју и аа је кроз Аијахронију, у зависности оА културног, Аруштвеноисторијског и политичког контекста, архетипска фигура побуњеника доживљаваца бројне варијације и метаморфозе, границе појма обухваћене тим термином постале су фмуидне ими растегьиве Ао свеобухватности.

Морис Фридман у књизи Проблематични побуғеник (1963) скренуо је пажњу на разцику између изворног и модерног прометејства, тј. на оно што је у тој представи специфично модерно. Прометејева побуна смислена је само $y$ оквиру старогрчког схватања космичког, Аруштвеног и културног поретка који митски јунак признаје као датост и који одређује безАична судбина (moira), моћнија и од самога Зевса. Насупрот њему, модерни Прометеј симболизоваће борбу против поретка, тј. против Бога који је изнад поретка (Fridman 2012: $34,389)$ и неће бити обдарен ни даром прорицања, којим је грчки Титан снажио свој пркос и своју наду. ${ }^{3}$ У доба када је „Бог мртав”, човек „осуђен да буде слободан” (Сартр), а наука, која је некада представљаца суштину прометејства, изокреће се против онога што је ьудско - Аа останемо само при узроцима и последицама о којима је Киш ватрено расправљао и у својим експиицитним коментарима - херојске поступке модерног Прометеја почели су да прате Аубоки унутрашњи сукоби. То значи да савременом човеку нису могле одговарати ни преАставе библијског побуњеника, ни романтичног хероја, па ни генијалног научника. Већ у књижевности друге половине 19. века јавьа се

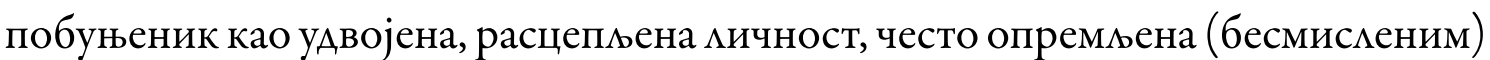
пркосом као најважнијом карактерном одредницом. У крајњој инстанци, он нити чује „глас из вихора”, нити је у стању Аа са̂м осмисли своју егзистенцију.

Поменута кретања идеја и значењска померања у односу на изворно прометејство учинила су да савремени побуњеник постане врно комплексна и парадоксална фигура - проблематични побуненик, а његова побуна одговор на његово изгнанство, на унутрашњу подељеност, на отуђење, на устројство света и апсурд живьења у свету без бога (Fridman 2012: 18). Фридман је то показао минуциозном анализом примера из књижевности друге половине 19. и прве половине 20. века (Мелвил, Аостојевски, Ками, Кафка), где је представьен побуњеник/ изгнаник који стацно осцимира између Ава типа - „модерног

\footnotetext{
${ }^{3}$ Митска прича каже Аа је Прометеј предвидео тренутак када ће и са̂м Зевс, мишен овога Аара, захтевати од њега да му прорекне судбину (испуњење Кронове кметве Аа ће из брака с Тетидом добити сина јачег од оца), што он одбија. То „предзнање” Аа његова патња на Кавказу ипак није вечна значи да је Титан полагао наде у будућност (Срејовић/ Цермановић Кузмановић 1992: 362-363).
} 


\section{Мирјана М. Бечејски}

Прометеја” и „модерног Јова” (Fridman 2012: 12). Први пркоси Богу (тј. поретку) и не признаје његову власт, док Аруги кроз дијалог с Богом (оАносно с апсурдом) „брани путове своје” и тражи смисао егзистенције. Овој ФриАмановој типологији могли бисмо додати још и „модерног гностика”, који се противи апсурду ими „зАом Аемијургу” и свим званичним религијама, тражећи спасоносни гносис у самоспознаји или уметничком стварању. Без препознавања ових типова историјских побуњеника тешко је проникнути у прометејско наслеђе савремене књижевности, гАе они нису само супротставњени него и парадоксално спојени, поготово у најсложенијим миковима и ситуацијама какве налазимо коА, нпр., Камија и Киша.

Аакме, прометејство је данас постало универзални књижевни појам за оАређени тип односа према стварности, за човеков став према постојању. А^и Аа бисмо неког сматрали модерним Прометејевим следбеником, он мора бити (трагични) побуњеник против ьудских ограничења, а његова побуна, ма како индивидуална била, мора имати и универзалну, хуманистичку суштину - мора инсистирати на питању смисла самог постојања.

Наш ция биће да пратимо и тумачимо појаву, развој, варирање и промишьање те проблематике у књижевном делу, по-етици и животној фимозофији Аанима Киша, почев оА раних есејистичких текстова, преко фигура побуњеника у његовој беметристичкој прози (избегавајући притом понавњање онога што је о њима у критици већ речено), па све до последњих есеја и интервјуа, у којима се писац опсесивно враћа прометејству и саิм се експиицитно преАставьа као модерни Прометејев следбеник. Како се наслов наше теме односи на цео пишчев опус, то је јасно Аа ћемо пажњу усмерити на главне типове побуњеника и да ће њихова представа бити нужно редукована. Такође, ауторска фигура побуњеника која израста из Часа анатомије морала би бити предмет засебног рада.

\section{Кишово промишьање прометејства}

Будући да је реч о бодлеровском типу писца - који зна шта ради и зашто то ради - заметак прометејских идеја у Кишовом делу треба тражити у његовој раној есејистици, која обикује манифестним аутопоетичким исказима. Већ у првом објавьеном есеју „Похваца спаљивању” (1957), он проглашава мичним откровењем став Џона Раскина: - 'Нешто доброга! Ако све није до- 
бро, онда ту уопште нема Аоброга' ( $\mathrm{Va}: 10) .{ }^{4}$ Потом у тексту „Космософијска екскурзија” (1957) налазимо овидијевски мајтмотив „човек загледан у звезде”, у „паскаловске ужасавајуће просторе” (Va: 12-17). А^и највише изненађују модерност и дубина с којом Киш још као студент промишьа прометејство у огледу „Мит о Прометеју” (1957), у ствари семинарском раду коА професора Мимоша Ђурића. Та модерност још више долази до изражаја поређењем са Аругим студијама чији су се аутори бавили истом проблематиком. На пример, јеАан паралемни поглеА на овај Кишов текст и на поменуту Фридманову књигу, и пореА нужне разлике у приступу, цияу, обиму, намени и стилу, показује подударност у избору грађе и низ сличних битних запажања.

Киш даје дијахронијски преглеА развоја идеје прометејства у књижевности оА Хесиода и Есхила до Жида, Сартра и Камија у скмаду са својом „поетиком сажетости", указећи у срж проблема готово песнички, помоћу поменутог симбома из Овидијевих Метаморфоза: Бог је створио сва жива бића погнутих глава, Аок је Прометеј створио једно биће уздигнуте главе. Тако „овај величанствени симбол говори очитије оА свих дефиниција прометејства: човек гордо уздигнуте главе, загледан у звезде" ( $\mathrm{Va:} 23$ ).

Погледајмо на којим је проблемима аутор инсистирао, шта је издвојио као прометејско наслеђе и на коју се митературу притом ослањао. Он запажа Аа се идеја прометејства у књижевности проблематизује оА момента када ХесиоА указује на двојну природу Прометејевих дарова човеку: ватру и моћ, културу и удањавање оА природе, а изнад свега свест и наду, који ће произвести с једне стране тежњу за слободом и једнакошћу с боговима, а с Аруге сазнање о пролазности и ограничености свега ьудског. ${ }^{5}$ „Мит о Прометеју је у ствари мит о буђењу ьудске свести", закьучује аутор (Va: 105). ПореА усмених преАавања професора Мимоша Ђурића, као помазиште су му могли послужити текстови „Трагедија Есхимова и њена етика” (Ђурић 1997а: 204-220) и кратак фимозофски и културноисторијски спис „Мит и смисао мита о Прометеју”, у ком је Прометеј тумачен као „Аоносимац и стваралац културе”, а богоборство

\footnotetext{
${ }^{4}$ С обзиром на то Аа смо користили издање Сабраних дела Аанила Киша у редакцији Мирјане Миочиновић 2006-2007, у парентезе које се односе на изворе уносићемо курзивно наведене скраћенице наслова књига и бројеве страница уместо уобичајеног начина за парентетичко цитирање. Попис скраћеница дат је уз изворну митературу.

${ }^{5}$ Фридман такође наглашава Аа „Прометеј, као човек, комбинује коначност ограничене моћи са знањем које надмашује ту границу у чину њеног сазнавања. Једино кроз чињеницу да је ьудско знање истовремено коначно и бесконачно он може спознати не само границе своје моћи већ и границе свог знања. Прометеј није напросто симбол ьудског знања и науке кроз генерације. Он је симбол двосмислености науке која проширује човекову власт и у исто време довоАи га ближе хибрису и самоуништењу" (Fridman 2012: 46).
} 
као развој човековог „индивидуалног ја” (Ђурић 1997б: 173-176). Киш је познавао и раА „Прометеј везани”, у ком професор прави паралеку између Есхимовог Прометеја и Гетеовог Фауста (Бурић 1997в: 151-167). Али док су Ђурићеви списи фимозофски и научни, чврсто ослоњени на историјске изворе и истраживања светских митолога, и са примарним цињем да буду информативни, Кишова емаборација теме је есејистичка. Премда је неспорно да и у информативном погледу тај текст премашује потребе студијског семинара (на шта указују широко поње истраживања и одлична упућеност у

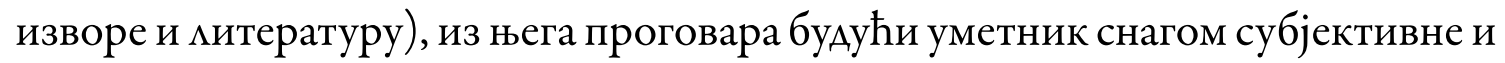
интуитивне визије. Митска фигура човековупца и бунтовника против богова оставима је трајан утисак на Киша и најавима тему која ће дубоко одјекнути у његовом животу и стваралаштву.

Посебно је битно да у овом есеју Киш увиђа суштински значај друштвеноисторијског контекста за књижевне трансформације идеје прометејства. Тако он наглашава да је у митерарној обради прометејског мита Есхим свео Бога на пуког тиранина, будући да је полету атинског демократског Аруштва претходимо ослобађање од тиранина: „А Прометеј је само инкарнација ьудске охолости. [...] Он хоће за себе (за ьуде) све и ни за Алаку мање савршено од Бога" ( $\mathrm{Va:} \mathrm{107).} \mathrm{\Lambda укијанову} \mathrm{сумњу} \mathrm{да} \mathrm{је} \mathrm{човек} \mathrm{достојан} \mathrm{дарова} \mathrm{и} \mathrm{херојске}$ патње Титана Киш тумачи идејном кризом горњих слојева античког друштва, закмучујући да „идеја прометеизма увек стагнира [...] уочи катастрофе” ( $\mathrm{Va}$ : 111). У Аањем прегледу аутор истиче Аа су средњовековна религиозна осећања произве а низ покушаја помирења Прометеја с Богом - а тиме су и саму идеју богоборства учинима апсурдном. У занимьивој парамели коју повцачи између Христове и Прометејеве жртве и трагике, између Христовог крста и Прометејевог бунта, његове симпатије су на страни пркосног Титана, који „неће Аа дели власт са тиранином и неће Аа изговори ниједну реч компромиса оА које би умро његов орао" ( $\mathrm{Va:}$ : 111). Уочьиво је Аа Киш овде још увек не прави чак ни имплицитно поређење Прометеја и библијског побуњеника Јова. (Те фигуре он ће мајсторски повезати у породичној тримогији, обликујући мик Оца.)

У овом крајње сажетом прегледу нашло се места само за она књижевна дела у којима прометејство добија нова, смела решења и трансформације. На пример, за Гетеову незавршену драму у којој је Прометеј „мАадалачки пандан његовом Фаусту”, „симбол уметника-ствараоца” што се гордо приближава Богу, ${ }^{6}$ или за романтичарске обраде мита о побуњенику: Бајронову (у мику

${ }^{6}$ „Гете је на тај начин у свом Прометеју спојио две есенцијалне теме своје ммадости: проблем уметника и проблем Титана. Ни у јеАном деку уметник није ближе 'богу' него 
Каина) и Шемијеву (Прометеј као оличење ьудске тежње за правдом), што је последње велико дело које прометејство схвата оптимистички.

Пошто је успоставио везе по вертикаци од антике до савременог доба, аутор највећу пажњу посвећује прометејским идејама у демима Ничеа, Жида, Сартра и, нарочито, Камија. Будући да је за ове писце-фимозофе „Бог мртав”, митски и романтичарски Прометеј Аоживео је метаморфозу у „грађанског Прометеја” и побуњеника против апсурда - проблематичног побуненика. „Прометејске тежње” нису задовољавајући одговор на питања човека атомског доба о смислу постојања: „Прастара сумња Аукијанова да је човек недостојан патње Титана у делу Камија и Жида има своје достојне настављаче. Ками, међутим, у мику уметника-ствараоца, налази једино откупьење, јеАини измаз. За Камија, митература, уметничко стварацаштво, само је облик конкуренције Богу, значи: и протест против Бога”, закьучује аутор ( $V a: 121)$.

Супротстављање смрти и пролазности стварацаштвом постаће и Кишове аутопоетичке идеје, које ће он уздићи на ниво животне филозофије. Као и коА Камија, те идеје биће тим трагичније што ће их пратити стално будна свест и о њиховој величини и о њиховом апсурду у стварном животу - о немогућности да се за прометејску ситуацију пронађе прихватьиво решење. ${ }^{7}$ Као и Ками, он је сматрао да једино у митератури/ уметности прометејска побуна има смисла,

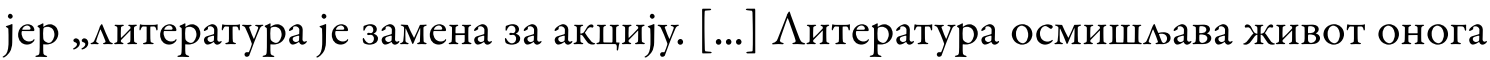
који пише и човека уопште” (GTI: 277-278).

Аакле, Аајући дијахронијски преглел развоја прометејства у књижевности од његовог зачетка до савременог доба, Киш у овом есеју с изненађујућом зрелошћу промишьа идеје херојског побуњеника у нехеројском времену и код Камија долази до најкомплексније фигуре проблематичног побуғеника, која манифестно заокупьа његову пажњу.

\section{Песничке фигуре модерног Прометеја}

Прометејске илеје су иманентно присутне у мичностима песника и писаца којима Киш посвећује своје наративизоване огледе, творећи оА њих живе есејистичке „Аикове”. Најзначајнији носиоци тих идеја у његовим раним текстовима јесу песник-револуционар Шандор Петефи (за кога истиче да је једини и оства-

у овом" (Va: 112-113).

7 „Писање ми пре свега служи као надокнада за живот који сам већ као дете замишьао друкчијим од оног који водим. [...] између свега онога што би човек могао да живи и онога што живи постоји огромна разлика. И стога мислим Аа ја (или било који други писац) замењујем те могућности живота једним измишьеним животом" (GTI: 280). 


\section{Мирјана М. Бечејски}

рио обе револуције), његов наследник Ендре ААи, те француски симболисти. ИзАвајамо модерног Прометеја који нам је представљен у есеју „Шарл Бодлер”, јер реч је о песнику који је своју егзистенцијацну побуну и стацну опсеАнутост смрћу пренео у уметничку сферу, постајући творац „поезије нужности”. У њој је увек присутан интелект да „организује $и$ иско треперење по строгим законима јеАне естетике и јеАне етике, и јеАног песничког и животног програма”, примећује Киш (Va: 308), а поезија је схваћена као духовна револуција која проширује хоризонте и осваја нове просторе слободе:

„Шта дакле проповеда Бодмерова по-етика?

Песник није дужан да обнавља свет кроз директну песничку акцију, јер његов је домен у трајању, у вечности, песник не треба да се потчињава практичним, утилитарним разцозима, он не треба Аа буде слуга прогреса, и стога није дужан да се ставьа у службу свакодневне пароле. Песник такође не треба ни да слика свет, јер реализам је таштина (и у томе он понавьа само стару платоновску тезу), нити треба да га објашњава, јер песник је Бог и Сатана истовремено, демијург, његов једини циь и начин

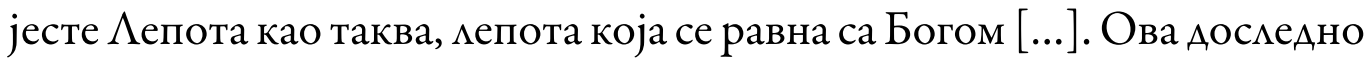
разрађена идеја мепоте, као и цело Бодлерово дело и његов живот, не беху само пусте песничке теорије и сање чија је он био узалудна жртва, како мисли Сартр, него се у тој идеји нацази начин испољавања опште фимозофије човека и природе, жива и жестока морална патња једног времена, надљудски покушаји да се оствари синтеза бића и поезије, Аа се утилитаризму супротстави идеја једне нове етике и естетике, јер поезија је заправо перманентна револуција" ( $\mathrm{Va:} \mathrm{313).}$

Све ово могло би се односити и на Киша ако реч поезија схватамо као и он, метонимијски за целокупну књижевност; јер и за њега је стварање бимо нужност, а не избор. Киш је уз то имао још једну зајеАничку, у основи јеретичку, опсесију с овим песничким бунтовником против устројства света: „створити једну књигу поетске квинтесенције, књигу у коју ће унети 'цело своје срце, сву своју нежност, целу своју веру (прерушену) и сву своју мржњу” ( $\mathrm{Va:} 307)$. У јеАном језгровитом есејистичком сегменту интервјуа „Аоба сумње” (1973) Киш ће истаћи да све време пише „једну књигу” и да је тежио Пешчанику Аати значење свезнадара, књиге неисцрпног метафоричког значења: „налик на Кабалу, са истим оним детерминантама које је овој последњој приписао Борхес: 'Књига у којој нема места случају, механизам с бесконачним бројем планова, с непогрешивим варијацијама, с вишеслојним посветьењем, чије 
нам откривање предстоји, књига, Аакме, која се Аа̂ испитивати до апсурда, Ао нумеричког бескраја...” (НP: 242).

Већ Кишова рана есејистика открива нам афинитет према субјективистичким фимозофима и према оним појединцима, епохама и покретима код којих постоји јединство етике и естетике, живота и митературе. „Заратустра, Буда, Христос - коА њих етика премази у естетику и обратно. [...], последњи циь уметности јесте 'преображење живота'. [...]. А последњи циь културе јесте 'преобраћање човечанства', подвмачи он тврдњу А. Бјелог (Va: 251-252). Аа је нарочито интересовање писац испољио за симболизам, како руски тако и француски, може се видети и по великом броју раних есеја које је посветио симболистичким песницима и по-етици овог покрета. О изненађујућој ширини и Аубини његовог истраживачког захвата критичари и историчари књижевности већ су Аали свој суд (Ивановић 1994: 74-75), а као одлично аутопоетичко образАожење те накмоности може нам послужити прометејски став да су симболисти „као и Ками, хтеми да супротставе Богу своје дело, говорећи емпирички, или, говорећи из социјалног аспекта, Аа супротставе своје Аело - ревокуцији. Аело, твораштво, демијуршки захват у звездану прашину - то је само облик конкуренције богу" ( $\mathrm{Va:} 255)$.

Пишчева опредеьења у овом раном периоду показују Аа није нимало скучајно што је јунак његовог првог романа једна превратничка песничка фигура.

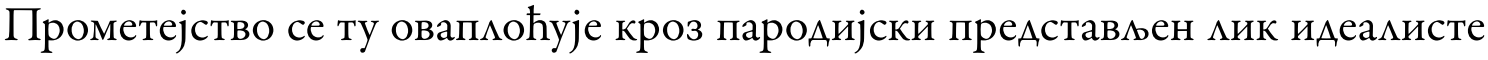
Ааутана, чији је прототип са̂м Киш из доба кад се „припремао да буде песник” ( $V a: 485)$. Аакле, студент светске књижевности, романтично-иронични побуњеник који и стварно и метафорично живи изоловано, на мансарди. Метафорично, то је свет $\Lambda$ итературе из ког он пркоси неромантичном хронотопу реалне егзистенције, коју настоји да му предочи реалистичко „ја” његове мичности, отеловьено кроз мик Јарца-Мудријаша. Студије књижевности јунак не схвата као своју будућу професију, већ као најдубьи унутрашњи позив, као предодређеност и као нужност. Природа његове побуне потпуно је ускцађена с таквим схватањем, јер она није усмерена на друштвени него на књижевни и културни поредак, који за њега представьа најстварнију стварност - призму кроз коју посматра свет и показује свој однос према њему. Пркос књижевним конвенцијама и увреженим културним схватањима манифестује се кроз ацузије на књижевна дела и јунаке, кроз цитате и „исправљање” матинских дикти, кроз креативни дијалог с кмасицима, те пародију „општих места”, на која ће се касније Киш обрушити Аиректно и жестоко као на „бога баналности”. 
Свака од анализираних прометејских фигура сложена је, контрадикторна и трагична, и све су Кишови блиски по-етички сродници. Ако се у овом раном периоду још и може говорити о архетипу херојског песника-побуњеника, он ће у његовом дему врцо брзо постати проблематичан.

\section{Ни Прометеј, ни Јов}

У породичној тримогији Аолази до Аубинских метаморфоза Кишових дотадашњих фигура побуњеника. Прометејске идеје јавьају се у Башти, пепелу и Раним јадима најпре кроз поступке Сина; на пример, када дечак ААи постаје свестан своје смртности и одбија да се помири с њом. У једном интервјуу писац то објашњава као почетак одрастања (GTI: 302). А^и, како је критика већ запазика (Ахметагић 2007: 78), о ААијевој наслеђеној богоборачкој природи најбоље сведочи тумачење Очевог Кондуктера, тј. учитавање у њега: „Са слепим бесом Прометеја и демијурга, мој отац није признавао даьину између земье и неба. У том анархичном и езотеричном новом завету бимо је посејано семе новог братства и нове религије, исписана теорија једне универзалне револуције против Бога и свих његових ограничења" (BP: 41$)$.

Из те „ишчашене” дечје перспективе израња $и$ Оца, један од најкомпиекснијих и најпарадоксалнијих иикова у српској књижевности 20. века. Аутор је овог кудог-цуциАног „фимозофа” и пијаницу мајсторски обликовао као проблематичног побуғеника „између Прометеја и Јова” - тачније, ни Прометеја, ни Јова - по чему се његова представа приближава Камијевој (Fridman 2012: 386).

Ако мит о Прометеју означава буђење човековог индивидуалног ја, онда Кишов породични мит о Оцу симболизује трагично настојање појединца Аа у неьудским условима то ја и сачува. Премда кроз његово чврсто етичко становиште да је боље бити прогоњени него прогонитељ такође проговара модерни Прометеј, овај се јунак не задовоьава једноставним прометејским избором или-или, који подразумева или уништење Аругог или уништење себе оА Аругог, тј. самоуништење (Fridman 2012: 386). Он захтева објашњење за своју ситуацију, он настоји да у општем бесмиску пронађе сопствени смисао и опредеьује се $и$ за побуну $и$ за дијалог. По томе се Е. С. ближи модерном Јову. Међутим, из јунаковог константног незадовољства небеском и земаьском хијерархијом, из његовог уверења да је Бог у равни појединачног искуства, а не институција, ${ }^{8}$ израња још један тип побуњеника који ће обележити Кишову по-етику - фигура гностика. 
Аакме, кроз поступке и „Белешке” лудака Е. С.-а преА читаоцем се одиграва Араматичан сусрет архетипских побуњеника, измештених из свог првобитног контекста: грчког, библијског и гностичког. У неколико трагично-ироничних сцена мајсторски нам је преАставњен „свргнути пророк”, бунтовник рођен „по окрутној могици небеске комедије, са посеченим кримима”, „титан без снаге титана" ( $B P: 122) .{ }^{9}$ Он нема храбрости да се на бимо који начин супротстави реалном непријатему (као грчки Прометеј), он не успева ни да продуби поверење током свог дијалога с Богом (као библијски Јов), нити пак Аа избави свој дух из тела и досегне спасоносну самоспознају (као гностици). Будући да снага његових замисли надмашују његову моралну снагу, а моћ фантазије истрајност и упорност, јунакова херојска борба искьучиво је унутрашња. Свака његова акција у спољашњем свету има супротан ефекат од жељеног: „прометејска” побуна чини га трагично смешним, дијалог с Богом остаје без разрешења и резултира још Аубьом сумњом и протестом, а муцидност/спознаја га не приближава Богу, него кудицу. Трагична парадоксацност овог Аика достиже своју куцминациону тачку када, насупрот крајње угроженом егзистенцијалном положају и лабилном психичком стању, насупрот чињеници Аа „у свету и са светом” није кадар да учини ништа (како је писац јеАном самоиронично констатовао за писце и митературу (HP: 74)), он у својим „бескрајним солимоквијима” не престаје да пркоси метафизичким силама. Своје критеријуме Отац увек изграђује с погледом упртим у небо и не задовољава се трошним, пропадьивим и несавршеним - оним што је Бог наменио човеку. Збуњен, анксиозан, непотврђен Аруштвено и мично, он је аутор незавршеног Реда вожне и ненаписаног романа - посебан сој Кафкиног „уметника у гладовању”.

Ипак, писмо које Е. С. оставња у последњим тренуцима живота и муцидности није само сведочанство прогоњеног већ и сведочанство његове метафизичке непокорности:

„Мој меш ће бити моја корабња, а моја смрт дуго пиутање по таласима вечности. Ништа у ништавику. И шта сам могао Аа супротставим ништавилу до то, ту своју корабьу у коју сам желео да сакупим све што ми бејаше блиско, ьуде, птице, звери и биье, све оно што носим у свом оку и у свом срцу, у троспратној мађи свога тема и своје душе. Жемео сам све то да имам крај себе, у смрти, као фараони у величанственом миру својих гробница, желео сам да буде све онако као што бејаше и

\footnotetext{
${ }^{9}$ На пример, сцена када Отац, глава породице, ноншалантно подупире врата својим чувеним штапом с гвозденим шиьком, „пружајући херојски отпор подАим нападачима” који проваьују у собу (BP: 53).
} 
пре тога: да ми у вечности певају птице. [...] Желео сам, дакле, и још увек желим, да одем из живота са специменима ьуди, флоре, фауне, Аа све то сместим у своје срце као у корабьу, да их затворим под своје капке када се они последњи пут спусте. Желео сам да прокријумчарим у ништавимо ту чисту апстракцију која ће бити у стању да се у тајности пренесе кроз врата једне Аруге апстракције, ништавне у својој неизмерности: кроз врата ништавима. Требало је, дакме, покушати згуснути ту апстракцију, згуснути је снагом воље, вере, интелигенције, кудима и ьубави (самољубња), згуснути је у толикој мери и под таквим притиском да задобије специфичну тежину која ће нас подићи увис, као балон, и изнети је ван домашаја мрака и заборава" (P: 265-266).

Та једина, „маха, ништавна”, а у ствари суштинска победа Е.С.-а наА сопственом пролазношћу представьа „поруку у боци” коју преА нама, као тајанственим адресатима, отвара Син. У критици је веома детаьно писано о томе на које све начине, с каквим циљевима и естетским ефектима Киш овом јунаку приписује сопствена по-етичка и животна уверења. Издвајамо закьучак изведен примиком читања Кишовог Аела „с Библијом у руци” - „Аа је поетичко усмерење ауторово бимо од исте врсте као и очево: богоборачко, мада свеобухватно и већ тиме библијско”, као и да оно није атеистичко, јер спор са Богом не може имати онај ко с њим није био у дијацогу (Ахметагић 2007: 79, 98). Киш је тај виА сопствене ремигиозности и експлицитно потврђивао. ${ }^{10}$

Овде ћемо споменути још једну варијанту Кишове модерне прометејске фигуре, премда је она далеко од модерног Јова. Реч је о револуционару Борису Аавидовичу Новском. За разАику од претходних побуњеника, он негира сваку стварност која је изнад њега, али тиме не повећава своју моћ, већ бреме одговорности за направьене изборе. Човек „од најтврђег материјаца” бива сломьен зарад идеје „о савршеној биографији”, коју сам изневерава. Кроз тај мик Киш илуструје радикални прометејски избор „ими-ими” и пародира идеју о Натчовеку: ${ }^{11}$ борећи се против зца, Новски је и са̂м постао змо; ими, Ка-

${ }^{10}$ „У Пешчанику сам хтео да постанем Бог, да заузмем очево место. ОАлучио сам да у 'катехизис' поглавьу Пешчаника наступим са откривањем сопствених осећања уместо очевих”; „Бог-Створитеь никада за мене није био обична метафора, то је уверење, не религиозно већ естетско" (GTI: 128, 178).

${ }^{11} А$ а је Киш и раније промишьао овај вид прометејске побуне сведочи његов кратак преводимачки поговор Сиду (1965) у светлу радикацних новина које је Корнеј увео у свет позоришта и уметности: одсуства Бога, раскида с аристотеловском поетиком и античким позориштем. Ту је човек као биће фатума замењен човеком којим управњају ум, воља, слава, касније оличеном у ничеовским „надьудима” (Va: 275). 
мијевим метонимијским речником, он радије бира да буде целат него жртва. Киш није случајно насловио своју збирку и истоимену приповетку Гробнича за Бориса Аавидовича, јер у светлу гностичког схватања да је тело гробница душе замисао о Прометеју-Натчовеку у њима је још јасније пародирана. Светом в ада зии Аемијург, или у најбоьем случају безиични хибрис, а слободна воьа, ум и слава, остају само пусти снови човека коме није дато да управља чак ни сопственом судбином. Као што је Е. С. судбински преАодређен да буде јоги, Новски остаје комесар.

\section{Гностички побуњеници}

Ааљи развој Кишових прометејских илеја уско је повезан с гностицизмом, што је јеАна од његових повцашћених тема у послеАњој деценији живота. Пошто пишчев однос према гностицизму представња широку и засебну тему, ${ }^{12}$ овАе ћемо пажњу усмерити на прометејске идеје које кроз гностички мит живе у причи „Симон Чудотворац” и есејима „Изгнанство и краљевство Марије Чудине” и „О Маркизу де Саду” (1988). Наиме, гностицизам представља религијски/ духовни покрет отворене синкретичке природе, који укьучује елементе источњачких религија и учења, грчких митова и неоплатонизма, манихејства, јудаизма, хришћанства, херметизма, чак и ацхемије, и практикује оригиналне начине мишьења и алегорезу (Lakarijer 2001: 41). Пошто су Кишу најближе управо оне његове компоненте које су преузете из прометејског мита, нас ће занимати како се у поменутим текстовима прометејска побуна сусреће с гностичком, тј. у њу се трансформише. А будући да и са̂м тон гностичких списа „саАржи у себи један призвук побуне и протеста” (Јонас 1971-972: 25), гностицизам је окарактерисан као „религија револта” (Барен 1971-972: 31).

Аанас не постоји довољно докумената на основу којих би гностичко учење бимо детаљно и поуздано реконструисано - како због његове амбивалентне природе и начелне усмерености против канона, догматских ограничења и Аефиниција, тако и због вековног прогона гностика. Упркос великим напорима научника, уз сваку дефиницију остале су широке ограде. Али оно што се поуздано зна јесте то да се гностичка побуна одувек односима на устројство овога света и његове институције, нарочито на званичне религије.

Киш је био одлично упознат с амбивацентном природом гностицизма, тако Аа је за тумачење поменутих есеја и приче од пресудне важности чињеница да је у оквиру гностичког покрета постојао велики броја школа, секти и зајеАница,

\footnotetext{
${ }^{12} \mathrm{O}$ томе смо писали у раду „Аанимо Киш и гностицизам”, који још увек није објавњен.
} 


\section{Мирјана М. Бечејски}

те да је њихов пут до гносиса могао бити и сасвим опречан - од потпуне аскезе (какву су, нпр., проводици „вацентинци”) до слободног схватања ьубави („симоњани” и тзв. „Симонијанске мистерије”) (Pejgels 1981: 140). Тиме се може објаснити велика размика између тихе резигнације и пркоса Марије Чудине, полемичких ставова и чудеса којима Симон Чудотворац негира Васкрсење, и Аеструктивне мазохистичке побуне Маркиза де Сада.

За свој анамитички есеј „Изгнанство и краљевство Марије Чудине” (1982) Киш је позајмио наслов оА Камијеве збирке прича с јасним циьем да повуче парахелу између гностичке поезије ове песникиње, фимозофије А. Камија и сопствених схватања. У поезији Чудине аутор види ремитологизацију гностичког мита о човечјем паду и изгнанству у овај свет, гАе су ьуди, „само сенке јеАне манихејске идеје зма, 'седименти изгубьеног неба' и блаженства, у вечној опозицији са Аемијургом". Наиме, гностици су вероваци да је овај свет творевина мажног Бога ими змог Аемијурга, који је заробио божанску искру у ьудско тело. Отуда познато гностичко схватање тела као гробнице душе, а овоземаьског живота као изгнанства. Међутим, човек се може вратити истинском Богу ако презре овоземаљске институције и разгори божанску искру коју у себи носи, тј. постигне гносис - (само)спознају, спасоносно, објавьено знање (Јонас 1971-1972: 19; Pejgels 1981: 16, 136). Аакме, изгнанство и ватра заједничке су кључне речи гностика и модерних Прометејевих потомака.

Марија Чудина до гносиса долази песничким стварањем. У њеној поезији Киш је препознао аутентичан глас гностичке песникиње „par excellence” и остварио бцискост с изабраном тематиком, „избор по сродству”. Опсесивне животне и стварацачке теме песникиње јесу и опсесивне теме А. Киша: смрт („семе смрти”, „бременитост” смрћу), обмана, безнађе, пролазност и сазнање о неминовности ьудског пораза, али и немирење с њима итА. Стварацачки симболи и метафоре такође су им блиски. На пример, симболика цвећа, руже, као знак да „семе смрти”, „семе распадања киија попут паразита у срцу мепоте”; пустиға (живьења) као синоним изгнанства; кула као ознака паралелног света „отетог оА ништавица” - света уметности, у који предодређени одмазе као у Аобровољно изгнанство („прибежиште од зАа, идеацан предео”, „Нојева барка која плута по свеопштем потопу, но плута”). „Јер та је кула подигнута упркос Богу, та кула је саграђена по идеалним плановима, то је идеална кула, вечни замак. Уметност је све, живот је ништа”. Међутим, и Киш је чедо сумње, те стога отвара димему да $\Lambda и$ је уметност достојна замена за живот, „да $\Lambda$ и се таштина живљења може надокнадити таштином стварацаштва”. Аа је живот ништа, то

172 је мако доказати, али нема доказа да је уметност све, понајмање да је вечна, 
истиче он, загледан у ову поезију колико и у сопствени живот и митературу. Јер ако је мепота пролазна и ако су сва бића смртна, дакме, несавршена, узалудан је сваки ьудски напор да се надрасте пролазност (НР: 127-128). Уметнику остаје само утеха да је, сукобивши те Аве таштине, покушао Аа оствари „једну мацу, ништавну победу" над свеопштим бесмислом.

Минуциозном анализом појединих песама Киш открива да је ово песништво „прожето Ао сржи гностичким одрицањем”, али да његово порекло не треба тражити у гностичким теоријама, него у гностичком духу песникиње: „гноса је матентно стање побуне и незадовољства стварањем и светом, поглеА на свет и живот, рекао бих биолошка суштина неких сензибимних бића; стога се тај гностички дух одржава кроз векове као матентна побуна, као немирење са устројством света, као хиперсензибилност и куцидност" (НP: 117-118). А буАући да гностици нису признаваци в аст и институције овога света, гностичка поезија не рачуна на допадање и успех, него на „вернике, оне који ће у њеном гласу, у њеном тихом нарицању и прокцињању пронаћи своје тајне мисли, свој глас" (НР: 123). Преносећи гностичко сазнање и побуну на свеколику поезију, тј. на књижевност и уметност, аутор уопштава своје закьучке:

„A ита је друго ова поезија, ита је поезија уопште, до то, тај крсни пут ка вишем сазнатьу, ка опасној луцидности која је чиљ себи самој, тај најхрабрији и најопакији демијртки чин: све схватити, све прихватити, лучидно и без обмане, и истовремено све одбачити у име те исте луцидности и прикључити се заточницима оне јединствене побуне чији је исход јасан. Супротставити Богу свој сопствени систем, један јединствен и нов генезис, један нов свет који није у складу са овим светом, једну лущидност која руши зграду стварағь, скрозирајући је једним јединим погледом презрена" (НP: 123-124).

У овим ставовима одјекује и гностички глас самога аутора, потврђујући да су најбоље странице његове прозе утемељене на сумњи и негацији више него на вери и афирмацији, на уметности у спрези са смрћу више него са животом, на побуни - упркос сазнању да је побуна можда узалудна. Али ваља нагласити и једну битну разАику: премда се и у Кишовом делу развија нека врста мита о човечјем паду и страдању, оно није само објава смрти и припрема за смрт већ и побуна у име живота. И док „Чудина своје виђење света као изгнанства и пакца најавьује сасвим у гностичком духу: презрењем. Прометејској побуни [...] она супротставља тиху резигнацију, презир" (НP: 116), Кишова је побуна гласна, прометејска. Као и професор Падовани - Кишов прототип ког упо- 
знајемо у његовој књижевној заоставштини - писац је „застао на пола пута и био спасен гностичке јереси" (Sk: 349).

Видели смо да су мичности којима Киш посвећује есеје, као и највећи број његових микова, све сами побуњеници и изгнаници. Несумњиво је да јеАну од најснажнијих еманација фигуре побуњеника међу њима представьа Симон Чудотворац. Писац истиче да је истоимена прича „варијачија на тему једне од гностичких легенди” (EM: 171). У ствари, у њој су полемички тематизоване Аве хришћанске мегенде о смрти гностичког учитеља Симона Мага и представьени су његово учење и митологизована историја. Прототекст приче представља есеј „Путеви Самарије” Жака Аакаријера, објавьен у књизи Гностици (2001: 39-50), ами је Киш користио и Аругу стручну $и$ тературу о гностицизму и симоњанима/ „Самарјанима”, познавао је гностичке текстове, хришћанске и паганске мегенде, као и сведочанство јеванђелиста $А$ уе у Аелима апостолским. Аокументарним изворима, текстолошком анацизом и идеолошким дискурсом Аетаљније смо се бавими у поменутом раду, а овде ћемо пажњу усмерити на прометејске идеје које су преко учења Симона Мага, аци и подстицане пишчевим опредеьењима, доспеме у његову причу.

Рађајући се, као и хришћанство, током првих векова наше ере у земьама Оријента, где су живу јудаистичку традицију окруживале бројне секте и тајне зајеАнице, гностицизам је усмеравао своју побуну првенствено на старозаветне текстове и на хришћанство као нову званичну религију. Као што Кишова прича преноси, на путевима Пахестине, Сирије, Самарије, Египта и Анадомије, први путујући пророци, „апостоли” гнозе, заиста су се могли Аиректно сусретати с Христовим ученицима. Аакме, Симон Маг је био савременик, а мегенде кажу и супарник апостола Петра, што је чињеница на основу које је писац домислио њихов конкретан сусрет. Преко јунакове минђуше у облику уробороса - змије која прожАире свој реп, Киш на почетку уводи у причу кьучни симбол гностичког учења и прави јасну алузију на његово духовно опредеьење. За гностике змија је савезница ьудског рода - симбол божанске мудрости и пандан првог гностика што у Еденском врту човеку преноси исконско знање о добру и зму, које је зми Творац намеравао да ускрати ьудима (Pejgels 1981: 16; Lakarijer 2001: 13). ${ }^{13}$

${ }^{13}$ У једном фрагменту из заоставштине Киш потврђује да је уроборос у његовој причи „јасан гностички симбол”: „слика бескраја, вртоглавица реинкарнације, егзистенције, као и мутан сексуални симбол, пун скривеног значења" (Sk:350). Међутим, змија има и општију симболику: она је симбол врачева и мага, неискупьене моћи природе, $а$ тентне моћи, ьудске радозналости, сазнања и сумње, истине и спознаје ујеАно, само- 
ЈеАан оА највећих побуњеника против званичне религије, „отац свих јереси” (Pejgels 1981: 79), Симон Маг је у ствари гностичка реинкарнација грчког Прометеја. За симоњане он је био оваплоћење Бога (Pejgels 1981:104), ${ }^{14}$ тим пре што је његов протест падао у доба апостолских проповеди и канонизације хришћанства. Као што је Прометеј имао пророчки дар и Аруге ванредне способности, Симон Чудотворац, „рођак” мегендарног чаробњака Фауста који употребњава забрањено знање и искуство, био је познат као Faustus ('ОбАарени') и поседовао је натприродне/ мађионичарске вештине (Fridman 2012: 47-48; Elijade 1991: 220). И о томе сазнајемо већ у сценама с ужетом на почетку приче.

Црквени историчар Харнак пише Аа је Симон Маг „прогласио доктрину у којој је чудно и наказно јеврејска вера помешана са вавимонским митовима којима су додати неки детањи из грчке митологије" (Čarobnjak Simon 2011, интернет). Премда Кишова прича више приказује него што развија детање Симоновог учења, Аа бисмо видели које су у њему прометејске компоненте, ми ћемо га сажето изможити на основу документарних извора које је писац користио. Иполит Римски, још јеАан оА главних хришћанских сведока овог учења, истиче Аа је овај јеретик тврдио како је „свако ьудско биће станиште, 'и да у њему станује неограничена моћ... корен свемира'. Али пошто та бескрајна моћ постоји у два вида, стварном и потенцијалном, та бескрајна моћ у свакоме живи у матентном стању, 'потенцијално, а не стварно'” (Pejgels 1981: 165). Симон Маг развија идеју како разгорети ту моћ и представња се као нови доносимац божанске ватре. О томе сазнајемо захваьујући Аакаријеровој „песничкој” реконструкцији у „Путевима Самарије”.

Наиме, Књига постања каже да је Јахве, Јехова или Елохим створитеь овога света. Симон то не пориче, али пориче Аа је он човекомубац и добри Бог. За то налази доказе у самим библијским текстовима. Елохим је најпре ААаму и Еви забранио оно што је најважније - сазнање добра и зма - а потом их је за прекршену забрану протерао из Раја. Све му то није бимо дововно, него је наставио Аа кињи њихове потомке: громовима, ватром, ратовима, болестима и свим могућим покорама до Потопа и после Потопа. Аакме, створитев из Постања је мажни Бог, „васељенски тиран”, „суАски извршитељ” и огорчени осветник, чији је једини циь „Аа осујети развој човечанства” (Lakarijer 2001:

сатируће и самообнавьајуће моћи итА. (Kuper 2004: 178; Gerbrajn/Ševalije 2004: 1013-1014).

${ }^{14}$ Постоји чак и мегенда Аа су му на Тиберу за време цара КАаудија Цезара (око 45. гоА.) Римьани подигли велику статуу с натписом „Simoni deo Sancto” („Свети бог Симон”) (Čarobnjak Simon 2011, интернет). 
42-43). То апсолутно одбацивање Откривења, које проповеда и Симон ЧуАотворац у Кишовој причи (EM: 12-14), створимо је непремостив јаз између гностицизма и хришћанства; тим пре што се гностици нису мирили с овом „неправдом”, већ су тражили пут ослобођења, пут ка спознаји истинитог Бога.

По мишьењу Симона Мага, тај пут крије се у самој човековој природи, која упркос Јеховином змом деловању, носи печат божанскога света. У скмаду с гностичким схватањем да је човек умањена слика васељене, Симон алегоријски тумачи Постање у Врту еденском и закьучује Аа „човек у свом теку носи реке еденске као што у својој души носи искру која потиче оА Бога истинитог. Он у себи чува, умањене, сажете, живе силе, кмице створења које су и клице васељене, а чији првотни, ујединитеьски принцип, јесте ватра" (Lakarijer 2001: 43-44).

Ватра и њена обличја - оА усијаног, преко стишаног/топлог Ао хАадног преАстављају велику Симонову опсесију (његову идеју о хладној ватри пригрмиће многи алхемичари), јер он је у човеку видео живо жариште у ком тиња и кружи божанска ватра. У ьудском телу она може имати духовни облик жудње (посебно за зачећем) и физички облик крви и семена, односно ммека. Божанска ватра човеку обезбеђује и друге урођене способности, помоћу којих се издиже изнад осталих живих бића: разум, језик и усправан став. Оне се могу, али не морају развити, што зависи оА самога човека и услова у којима живи. И ту смо код најважнијег начела, по коме се ово учење супротставља јеванђељском: и „Ауша није бесмртна по природи, она само може Аа буде бесмртна, ако човек оАржава, храни ту повлашћену ватру коју у себи носи. У противном се неминовно враћа ништавику" (Lakarijer 2001: 45). ${ }^{15}$ Божанска ватра, вера у човекове потенцијале које треба пробудити, покушај Аа се сопственим снагама домаши бесмртност - све нам то говори аа је Симон Маг био велики Прометејев потомак и Кишов духовни сродник.

$\triangle \mathrm{a}$ би то постигао, човек мора Аа презре овај свет и његове институције. Како то чинити у свакодневном животу, Симон је показивао сопственим примером. Наиме, Симонова пратиьа, у причи названа Софија Проститутка, а у документима позната као робиња и проститутка Хелена из Тира, има веома важно место у овом верском систему. Она је „Симонов женски дупиикат”, што је стара вавилонска идеја о мушком и женском религијском принципу (Čarobnjak Simon 2011, интернет). За симоњане она је отемотворење божанске мисли, тј. Прва Мисао, против које су се побуними анђели заробивши је у женско тело. Отада је прошла кроз више реинкарнација, а најпознатија је она Хемене Тројанске. Анонимни аутор истиче да је код „Самарјана” то Сукот-Бе- 
нот, позната и као богиња Венус, чији су се богомољци стално проституисали, a Хемена је исто што и Ауна, сиријска и вавилонска богиња месеца (Čarobnjak Simon 2011, интернет). О њој налазимо податке и у Откривеву Јовановом (2: 20-21), где апостол Јован истиче да ова „Језавела” себе сматра пророчицом. Већину ових података Киш је сажео и уткао у своју причу (EM: 16).

Из уверења Аа су он и Хемена реинкарнација прапочетног пара и да жена сапостоји са мушкарцем (за разлику оА „крње слике” пара који представља Библија), оваплотиће се Симоново учење: душевна и телесна жудња средства су човековог ослобођења: „Он, Симон, и она, Хелена, својом узајамном жудњом за сједињењем у телу и души, васпоставиће првобитни поредак света и пренеће коначно поруку жудње коју је 'пресрео' Јехова. Водите ьубав, вели Симон, Аа се одупрете збрци света, да васпоставите жудњу у њеној суштинској сврси, Аа одржава творачку ватру која је крв, ммеко и семе" (Lakarijer 2001: 46-47).

Насупрот оним гностичким школама које су упражњавале аскетизам и чија се побуна односила на све материјално и путено, симоњани су проповедали слободно вођење ьубави и живели су у ванбрачним заједницама које су и међусобно општиме не чувајући се зачећа. Битно је само Аа се оно не одвија поА контролом установа. Већ овакав начин живота, познат као „Симонијанске мистерије”, морао је саблазнити хришћане (Lakarijer 2001: 47; Klajn 2017, интернет). У обе верзије Кишове приче Симон Чудотворац се противи одбацивању телесних наслада, тврдећи да је жена „врч нектара” и „урна блаженства”: 'Свака је земьа земьа и свеједно је где човек сеје. Права је заједница када се човек ижена измешају' (EM:24). Ове речи нису измишьене, већ представьају јеАан од Арагоцених цитата Симона Мага које бележи Иполит Римски, а Киш их преузима оА $\Lambda$ акаријера (2001:47). С обзиром на то Аа се Киш „није усуђивао да измишьа", а да су ове речи сигнали за препознавање симонијанског учења међу бројним гностичким школама, оне су и у причи издвојене курзивом као посебно значајна рецепцијска смерница, упућена „пажьивом читаоцу”. Он не спомиње „Симонијанске мистерије”, нити ближе објашњава шта су ове речи значиме за посвећенике. А могме су значити да је свака врста стапања божанских искри жудње и бића једна мала ьудска победа над светом змог демијурга, у чијој је природи расипање, раздвајање и отцепьење. У хришћанским документима остало је сведочанство да је Симон Маг сабирао те искре у буктињу, проповедајући: „Ти и Ја смо тек ЈеАно” (Lakarijer 2001: 48).

Кишова прометејска прича тек ту почиње, рачунајући, као и обично, на читаочево предзнање. Аакме, писац се и овде показује не као мајстор измишљања, него као мајстор сажимања и документарног приповедања. Он полази оА тен- 
Аенциозних хришћанских мегенди о смрти јеретика Симона Мага - од места гАе се $\Lambda$ акаријерово есејистичко казивање завршава - Аа би створио херојску и трагичну фигуру гностичког Прометеја, који се жестоко супротстављао постојећем устројству света.

Аоследан идеји да је књижевност „Књига мртвих”, Киш путем естетске форме разгрће вео неправде наА Симоном Магом, ког је канонизована, победничка Историја осудима као једног од најстаријих мислимаца гнозе, и уздиже га до симбола свих оних неименованих „чеда сумғе” који су постали ими ће тек постати њене жртве.

Није случајно да гностичка побуна најгласније одзвања пишчевим последњим есејима, као и целом збирком Енииклопедија мртвих. Сама замисао енцикмопедије посвећене мртвима за које није бимо места ни у једној званичној енцикмопедији - што је тема насловне приче - представьа прометејску побуну. Такав свезнадар успоставља нов поредак и пркоси историји, инсистирајући на вредности појеАиначног и мичног. У јеАном интервјуу писац ће и изјавити Аа је за њега Неименовани „највећа жртва Историје”: „Неодређеност Историје постаје један одређени појединац, а књижевност исправьа равнодушност историјских чињеница. КаАа кажем исправити Историју књижевношћу, мисмим на следеће: како дати равнодушности Историје својство конкретног и истинитог ако не остацима аутентичних докумената, писмима и предметима који носе трагове стварних бића" (GTI: 185).

Већ је примећено да има нечег судбинског у томе што се, описавши пун круг, идеји прометејске побуне Киш вратио и у свом последњем есеју, „О Маркизу де Саду” (1988) (Miočinović 2007: 563). ОглеА посвећен писцу који се на свој начин „рвао са небеским устројством” несумњиво иде у реА његових најлепших текстова. Мајсторски користећи фигуру порећења, он већ у првој реченици износи једну смеку хипотезу: „Џиновска фигура Маркиза де Сада, 'огромна и језива' (Свинберн), комплементарна је великој француској револуцији, чијим је он савремеником и био. И Аок се револуција разрачунавала са историјом, немилосрдно проливајући крв у име земаљског прогреса, 'божанствени Маркиз' рвао се са небеским устројством. Јер СаА је био прометејски ребел; револуција је за њега само изговор, само бледа слика његовог метафизичког ограшја" ( $Z L$ : 74). Цео есеј представьа објашњење тог става.

Аичност и Аело овог великог противника Бога и институција, гностичког

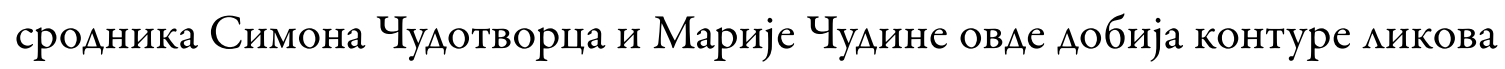
наративне прозе. Аیи, за разАику од песникињиног тихог презира према свету 178 змог демијурга, ими јеретичког мисионарства Симона Мага који води распре 
с апостолима хришћанства, Ае СаА је радикални побуњеник против мажног морала и утешитеьске улоге религије:

„Он је идеји прогреса супротставио свој песимистички концепт човека баченог у свет: човек тежи апсолуту, и стога му нема утехе. Садов је песимизам један од најмрачнијих, најтемеьнијих и најдеструктивнијих за које фимозофија зна. Јер док су песимистичке или фаталистичке Аоктрине у крајњој консеквенцији проповедаце мирење са судбином, пасивност, нирвану, Садов је песимизам агресиван” ( $\check{L}: 79)$.

У његовој филозофији живота и стваралаштва не постоје ни прошиост ни будућност, а једина садашњост су зАочин и сладострашће - и то без ьубави и радости, надомак смрти: „Јер овде је, рекосмо, разблудност дата у чистом стању, као субцимација; гола, не као голо тело, него као гола идеја, као јасна теза: Бога нема, авај!” (ŽL: 77-78) ИАи, како метафорично истиче аутор, у Ае Садовом свету Ерос и Танатос су једини богови. Ту је бкуА „религијски чин”, а зАочин „акт побуне, једини акт по мери човековог сазнања о свету” (ŽL: 79).

Упознат са разгранатим гностичким учењима, Киш скреће пажњу на радикално крицо чији је наследник био Ае СаА. Иако он то кримо не именује, на основу претходне реконструкције можемо претпоставити да је реч о радикамизацији симоњанског учења. У свету апсурда и случаја „просвећеном гностику остаје само мимезис природе као чин крајњег очајања и побуне” (ŽL: 79), па Ае СаА користи ьудско тело као средство.

Премда је Кишу гностичка побуна бима по-етички блиска, а Ае Садов песимизам разумьив, он показује отворено неслагање с овим њеним агресивним видом који је „своју метафизичку побуну пренео и на земне пределе”, спустивши на земьу Пакао, и који, поврх свега, искьучује ьубав. Аругим речима, као оличење безнадежне побуне која остаје самој себи сврха, Ае СаА је једна крајње проблематична фигура побуњеника. За разАику оА Аревних гностика који у гнозису виде могућност спасења и поновног сједињења с Богом, у Ае Садовом свету зцо се цикцично понавьа и спасења нема. Његово је дело „бриьантна икустрација једне једине илеје, јеАне јеАине опсесије: ьудске егзистенције као пораза" ( $\check{L} L: 80)$. А Киш је пркосни Прометејев наследник и он се с таквим поразом неће помирити.

Стварајући микове Прометејевих потомака, Киш је у њих утиснуо снагу сопственог, изворног доживљаја. У једном ауторском коментару он истиче да је мик Симона Чудотворца његов сродник и плод његових сопствених опсесија и побуна: „То је нека врста побуне против човекове смртности и против поретка 


\section{Мирјана М. Бечејски}

који вцада светом"; „Ја сам незадовоьник. Незадовољан сам пре свега самим собом, својим животом, својим писањем, политичким поретком, начином на који је уређен свет” (GTI: 279, 280). А на другом месту изјавьује: „Моја спиритуанност је гностичка у смиску који сам описао у Енииклопедији мртвих. Суштина те спиритуалности је моје незадовоьство овим светом. Ја сам нека врста побуњеника против Божје творевине” (GTI: 345).

Аакме, прометејство од почетка живи и у духу самога Киша, не само као манифестна по-етичка идеја него и као начело његове животне филозофије, његов поглед на свет. Наиме, оА раног есеја „Похваца спаьивању”, преко јавних интелектуанних иступања и књижевне полемике која је за њега преАставьаца питање живота, па до фаталистичког тумачења сопствене болести као казне ${ }^{16}$ и њеног преношења на метафорички, поетички пиан, ${ }^{17}$ Киш ће остати бунтовник против канона, догматског мишьења и општих места, „рашчовечења митературе” и безАичности историје, антропоцентрични јеретик „у вечној опозицији са демијургом" - модерни Прометеј par excellence.

Примери узети из читавог Кишовог опуса показују аа су развој прометејских идеја и њихово промишьање ускцађени с магистранним књижевним и идејним токовима, с „гибањем светског духа”. Притом је важно нагласити Аа његово прометејство није никаква „књижевна мода”, него једна од оних опсесивних тема које су га обележиле, саставни део његове животне филозофије. Киш ту не следи књижевне узоре и постојеће типове, већ даје аутентична, изузетно модерна и комплексна виђења индивидуацних побуна, често без разрешења, али увек запитана преА смислом егзистенције. Ако се из њих може назрети Кишов одговор на то питање, онда је он несумњиво у уметничком стварању као прометејском покушају да се помере трагичне границе ьудског живота и сазнања.

\section{Извори:}

1. Kiš, Danilo (2006-2007), Sabrana dela Danila Kiša: u redakciji Mirjane Miočinović, Beograd: Prosveta.

${ }^{16}$ „Зато што сам изигравао творца, зато што сам конкурисао Богу”; „Питам се, наиме, није ми већ и само писање нека врста казне. Пре свега ако тако као ја озбиьно схваташ писање" (GTI: 290, 292). „Заправо, ствараш 'вештачки рај'. [...] Писац ради нешто што нормални ьуди не раде. Он води опасан двоструки живот. Он се игра ватром, животом, он покушава Аа дотакне апсокут који је недодирьив или можда такав треба да остане. Он жели да убере забрањено воће." ${ }^{17}$ „Моја болест је трагање за апсолутом посредством књижевности” (GTI: 292-293). 
Попис скраћеница: Va - Varia, P - Pešcanik, HP - Homo poeticus, EM - Enciklopedija mrtvih, Sk - Skladiste, BP - Basta, pepeo, $\check{L} L$ - Život, literatura, GTI - Gorki talog iskustva.

\section{Цитирана митература:}

1. Ахметагић, Јасмина (2007), Аажд одживога угљевља: (читағьес Библијом у руци: проза Аанила Киша и Мирка Ковача), БеограА: Араслар партнер.

2. Барен, Т. П. ван (1971-1972), „Ка Аефиницији гностицизма”, превела Арагица

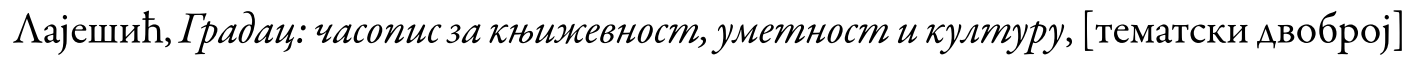
Гностищизам, ур. Аушан Ђорђевић Мимеуснић, 28-31.

3. Библија или Свето писмо Старога и Новога Завјета (1985), превели Ђура Ааничић (Стари завјет) и Вук Стеф. Караџић (Нови завјет), БеограА: Британско и инострано бибцијско Аруштво.

4. Gerbrajn, Alen, Žan Ševalije (2004), Rečnik simbola: Mitovi, snovi, običaji, postupci, oblici, likovi, boje, brojevi, prevod i adaptacija Pavle Sekeruš, Kristina Koprivšek, Isidora Gordić, Novi Sad: Stylos: Kiša.

5. Ђурић, Милош Н. (1997а), Хеленска ктижкевност и компаратистика, Изабрана дела Милоша Н. Бурића, БеограА: Завод за уџбенике и наставна средства.

6. Бурић, Мияош Н. (1997б), Културна историја и рани философски списи, Изабрана дела Милоша $Н$. Бурића, Београд: Завод за уџбенике и наставна средства.

7. Ђурић, Мимош Н. (1997в), Философски списи, Изабрана дела Милоша Н. Ђурића, Београд: Завод за уџбенике и наставна средства.

8. Elijade, Mirča (1991), Istorija verovanja i religijskib ideja 2: Od Gautame Bude do trijumfa hrišćanstva, prevela Mirjana Perić, Beograd: Prosveta.

9. Ивановић, Радомир (1994), „'Тешке игре писане речи' (Свест о модернитету или рана есејистика Аанима Киша)", зборник Ноттаgе Аанилу Кищу, ур. Радомир В. Ивановић, Подгорица - БуАва: Кумтурно просвјетна заједница БуАва - СреАња школа „Аанимо Киш”, 57-77.

10. Јонас, Ханс (1971-1972), „ОАређивање типомошких и историјских граница гностичког феномена", превео Новица Петровић, Градаи: часопис за къижевност, уметност и културу, [тематски Авоброј] Гностищизам, ур. Аушан Ђорђевић Мимеуснић, 19-28.

11. Klajn, Oliver, Simon Mag, dostupno na $<$ http://www.planeta.org.rs/30/2\%20legende. $\mathrm{htm}>$ (pristupljeno 24. juna 2017).

12. Kuper, Džin Kembel (2004), Ilustrovana enciklopedija tradicionalnih simbola, preveo Slobodan Đorđević, Beograd: Nolit.

13. Lakarijer, Žak (2001), Gnostici, Preveo Milojko Knežević, Predgovor Lorens Darel, Čačak: Gradac. 


\section{Мирјана М. Бечејски}

14. Miočinović, Mirjana (2007) Pogovor, U: Danilo Kiš, Varia, priredila Mirjana Miočinović, Sabrana dela Danila Kiša: u redakciji Mirjane Miočinović, Beograd: Prosveta, 559-570.

15. Pejgels, Elejn (1981) Gnostička jevandelja, prevod i predgovor Zoran Minderović, Beograd: Rad.

16. Срејовић, Арагослав, Александрина Цермановић Кузмановић (1992), Речник грчке и римске митологије, БеограА: Српска књижевна задруга.

17. Fridman, Moris (2012), Problematični pobunjenik: Melvil, Dostojevski, Kafka, Kami, preveo Igor Javor, Beograd: Službeni glasnik.

18. Carobnjak Simon, dostupno na <https://dobravijest.files.wordpress.com/2011/11/ simon_mag.pdf2011> (pristupljeno 5. juna 2017).

\section{PROMETHEAN IDEAS IN THE OEUVRE OF DANILO KIŠ}

\section{Summary}

With a view to keeping track and interpreting the emergence, development, and variations of Promethean ideas in the oeuvre and life philosophy of Danilo Kiš, the very notion of Prometheism in contemporary literature, as well as the reflections of the author himself on the subject, is shed some light upon. Using the typology of the modern rebel/ outcast from Maurice Freedman's Problematic Rebel ('modern Prometheus' and 'modern Job') as a point of departure, the first figures to be analysed are those of the rebel-poet in $\mathrm{Ki}$ ['s early essayistic works, then those of 'problematic rebel' between 'Prometheus and Job' in his family trilogy and Prometheus-Übermensch in A Tomb for Boris Davidovich, with closing accounts on gnostic rebels in the story of " $\mathrm{Si}$ mon the Magician" and in some of his last essays and interviews, in which the author makes an obsessive comeback to Prometheism and explicitly presents himself as a modern rebel. Though Kiš himself offers no typology of the rebel figure, he does broaden the scope of the notion of Prometheus/ Prometheism to numerous variants and transformations, including the notion of rebel in ironic-parodic context, as well as that of 'modern gnostic'. 